\title{
Analysis of Daily Rainfall in São Carlos/SP, Brazil over 1979-2017 Using Laplace Trend Test
}

\author{
Rafael Grecco Sanches', Bruno César Dos Santos', Rodrigo Sanches Miani², \\ Gustavo Zen de Figueiredo Neves' ${ }^{1}$, Mauricio Sanches Duarte Silva ${ }^{1}$, \\ Adriano Rogério Bruno Tech ${ }^{3}$
}

\footnotetext{
${ }^{1}$ São Carlos School of Engineering, Program in Environmental Engineering Sciences, University of São Paulo (USP), Sao Carlos, Sao Paulo, Brazil

${ }^{2}$ School of Computer Science, Federal University of Uberlândia (UFU), Uberlandia, Minas Gerais, Brazil ${ }^{3}$ Department of Animal Science and Food Engineering, University of Sao Paulo (USP), Sao Paulo, Brazil Email: rafagsanches@usp.br
}

How to cite this paper: Sanches, R. G., Santos, B. C. D., Miani, R. S., de Figueiredo Neves, G. Z., Silva, M. S. D., \& Tech, A. R. B. (2020). Analysis of Daily Rainfall in São Carlos/SP, Brazil over 1979-2017 Using Laplace Trend Test. Journal of Geoscience and Environment Protection, 8, 104-125. https://doi.org/10.4236/gep.2020.87006

Received: June 8, 2020

Accepted: July 24, 2020

Published: July 27, 2020

Copyright $\odot 2020$ by author(s) and Scientific Research Publishing Inc. This work is licensed under the Creative Commons Attribution International License (CC BY 4.0).

http://creativecommons.org/licenses/by/4.0/

(c) (i) Open Access

\begin{abstract}
Rainfall expresses one of the most complex climate factors in Southeastern Brazil. Understanding the dynamics and temporal trends of rainfall represents a significant challenge due to regional and even global mechanisms, such as FS (Frontal Systems) and the SACZ (South Atlantic Convergence Zone), and the interaction with the Atlantic and Pacific Oceans. The present study aimed at analyzing the pluviometric tendencies in São Carlos/SP, in the countryside of São Paulo State. Laplace trend test was used to comprehend the temporal evolution of daily rainfall in the region in the historical series 1979-2017, in seven pluviometric stations (climatological or surface stations). Significant fluctuations in interannual trends and between seasons were observed. However, it was noted that the beginning of the 1980s showed positive trends, whereas, as of the year 2000, most of the stations demonstrated negative trends, indicating a reduction in daily rainfall volume due to the great tropical climatic variability of Brazil. Emphasis should also be given to the regional and local effects, such as elevation and urbanization, respectively, which corroborate such differences among the analyzed stations. This methodology is of considerable value for the observation of pluviometric trends, and future studies can validate such a tool in climatological studies.
\end{abstract}

\section{Keywords}

Tropical Climatology, Climate Variability, Rainfall Trends, Statistical Tool, Laplace Trend Test 


\section{Introduction}

Several pluviometric anomalies occur in Brazil, such as in the northeastern drought polygon and extreme events in the southern portion of the country, where interactions between tropical and extratropical systems are present, as well as the South Atlantic Convergence Zone (SACZ) and frontal phenomena, which result from the air masses that predominate in the region. These interactions are of significant interest in regional planning due to the high degree of interference, impact, and spatiotemporal repercussion (Sant'Anna Neto \& Zavattini, 2000).

It is also noteworthy that frontal systems (FS) and the South Atlantic Convergence Zone (SACZ), among other atmospheric mechanisms, represent some of the primary elements associated with rainfall in the region. These mechanisms are correlated through teleconnections or Ocean-Atmosphere-Continent interactions (De Carvalho; Jones, \& Liebmann, 2004; Kayano \& Capistrano, 2014).

In southeastern Brazil, such anomalies can be verified by influencing trends regarding increasing or decreasing temperatures, as well as tendencies in rainfall volumes (Kayano \& Capistrano, 2014; Pscheidt \& Grimm, 2009; Vásquez et al., 2018).

Teleconnections contribute to the understanding of climate fluctuation through data concerning the Atlantic and Pacific Oceans, such as the AMO (Atlantic Multidecadal Oscillation), the phases of the El Niño-its positive phase (ENSO - El Niño Southern Oscillation; increase in Pacific temperature) and La Niña-its negative phase (cooling of Pacific temperature), and the PDO (Pacific Decadal Oscillation), for example. In the Brazilian Southeast, the rainfall trends influence the tendencies of temperature increase/decrease (Drumond \& Ambrizzi, 2008; Evangelista et al., 2007; Kayano \& Capistrano, 2014; Pscheidt \& Grimm, 2009; Vásquez et al., 2018).

The landscape of the studied area is also a significant aspect to understand the regional rainfall behavior. Due to atmospherical dynamics, it is influenced by the humidity stemming from the Tropical Atlantic Air Mass, which corroborates in consecutive wet days, as well as the seasonal rainfall values for the area (Zandonadi et al., 2016).

A number of studies (Dufek \& Ambrizzi, 2008; Liebmann, Jones, \& De Carvalho, 2001; Lima, Satyamurty, \& Fernández, 2010; Silva Dias et al., 2013; Zilli et al., 2017) have analyzed the temporal distribution of rainfalls and their temporal trends, as well as the increase in rainfall volume, as observed in São Paulo State, mainly concerning extreme values, regardless of recent dry periods, i.e., of prolonged drought (Zilli et al., 2017).

The regional characteristics contribute to understand the regional climate specificities in São Paulo State. Several regional assessments have been conducted focusing the analyses of the increase/decrease trend in rainfall, the increment in the episodes of extreme rains (over $40 \mathrm{~mm}$ ), due to their magnitude and frequency, the increase in daily pluviometric values, and the changes ob- 
served in the last century regarding rainfall in southeastern Brazil (Marengo et al., 2010; Sugahara, Rocha, \& Silveira, 2009; Zilli et al., 2017).

Dynamic atmospheric mechanisms, such as the SACZ, Frontal Systems (FS) and the influence of oceanic temperature anomalies (Atlantic and Pacific), can contribute with changes in rainfall, especially in intense and extreme rain events (Cavalcanti, 2012; Haylock et al., 2006; Lima, Satyamurty, \& Fernández, 2010; Muza et al., 2009; Rao et al., 2016; Serra et al., 2014).

The predominance of extreme events caused by frontal systems (53\%) in the region (Lima, Satyamurty, \& Fernández, 2010), the increase in rainfall volumes due to oceanic anomalies and the pattern of urbanization (Cavalcanti, 2012; Kayano \& Andreoli, 2007; Kayano, De Oliveira, \& Andreoli, 2009; Zilli et al., 2017), and even changes at the beginning and end of the rainy seasons have also been reported (Rao et al., 2016).

Moreover, several remarks have been made regarding changes in the regional pattern of rainfall in Southeast Brazil, specifically in the State of São Paulo, including its urban and elevation effects. Among them, some authors suggested the increase in rainy days with low volume of rainfall (Haylock et al., 2006), the concentration of the rainfall volume during a smaller period of rainy days in the State of São Paulo (Dufek \& Ambrizzi, 2008), as well as their alterations in extreme patterns (Zilli et al., 2017).

Due to the regional aspect, in inner São Paulo, a region close to the targeted area in the present study, notes regarding changes in total, interannual, and extreme rainfall regimes have been highlighted, in addition to emphasizing the influence of oceanic anomalies in the area (Blain, 2011, 2013; Sanches et al., 2018; Santos et al., 2012; Santos, Souza, \& Vecchia, 2017; Youlton et al., 2012). The Laplace trend statistics give a clear picture about the possible trends in a dataset. The proposed approach consists of examining the trend values of pluviometric data over a given period and identifying tendencies of global rainfall increase or decrease over such a period and, when appropriate, to analyze the trends locally. To the best of our knowledge, this is the first paper that uses the Laplace Trend Test for rainfall analysis. These remarks convey the need to observe the temporal evolution and rainfall trends in the area. Thus, the objective of this study was to analyze the pluviometric trends in São Carlos/SP region with the Laplace Test statistical tool (Kanoun, Martini, \& Souza, 1991).

\section{Methodology}

\subsection{Data and Study Area}

It was selected to analyze the rainfall trends in São Carlos/SP data from the historical series 1979-2017, from seven pluviometric stations located in different points of the municipality, as shown in Table 1.

The input pluviometric data were daily and, due to errors in some years, the gaps were discarded to carry out the calculations. However, the flaws in data did not compromise trend calculations (below $5 \%$ of missing data, and trend factor 
Table 1. Description of the pluviometric stations in the São Carlos/SP region.

\begin{tabular}{ccccccc}
\hline Name station & $\begin{array}{c}\text { Responsible } \\
\text { authority }\end{array}$ & City & Lat & Long & Altitude & Years \\
\hline Capão Preto & DAAE-SP & São Carlos & -215212 & -474800 & 610 & $1979-2014$ \\
Barra & DAAE-SP & São Carlos & -215380 & -474790 & 610 & $1979-2017$ \\
Água Branca & DAAE-SP & São Carlos & -224300 & -482460 & 598 & $1979-2017$ \\
Santa Bárbara & DAAE-SP & São Carlos & -226000 & -475848 & 780 & $1979-2017$ \\
Santa Eudóxia & DAAE-SP & São Carlos & -214648 & -474648 & 620 & $1979-2017$ \\
UFSCar & INMET & São Carlos & -215737 & -475137 & 856 & $1979-2017$ \\
Ribeirão Feijão & ANA & São Carlos & -229000 & -475324 & 676 & $1979-2016$ \\
\hline
\end{tabular}

calculates each one data) and, since they were recorded on a daily basis, filling techniques were not applied (Table 1). The spatialization of the pluviometric stations is shown in Figure 1.

The city of São Carlos/SP is located in the countryside of São Paulo State, southeastern Brazil, under an alternating rainy and dry climate regime. In this area, summer is the season that retains the most significant accumulated pluviometric values (hot and humid period), known as the hydrological period (between October and March), and its temperature is higher than in winter (Santos, Souza, \& Vecchia, 2017). Thus, there are distinguishable variations between elevated and mild temperatures in June, July, and August, with concentrated precipitation in December, January, and February.

The studied area is situated in a plateau region on the edge of the sandstone cuestas of Serra Geral, denoting the action of air masses and orographic rainfall, as well as frontogenetic phenomena in the regional geographical dynamic (Tolentino, 2007).

The geomorphological compartment of the analyzed region exhibits altitudes varying from 800 to $1000 \mathrm{~m}$. The rainier quarter occurs between December and February, with annual rainfall between 1500 and $1800 \mathrm{~mm}$.

\subsection{Methods}

The temporal observation of rainfall is of substantial interest, although different techniques are employed for spatial and temporal analyses. Thus, the observation of tendencies at pluviometric stations comprises the main form for their understanding and applicability, such as frequency, peaks of variance, and significance, among other statistical aspects.

The analysis of rainfall trends, in pluviometry, enables to more easily understand heterogeneous data and information from large databases (big data). The techniques applied for the observation of these tendencies aim to analyze statistical significance and correlations using non-parametric tests, including the Mann-Kendall, Kendall, and Pearson-linear correlation tests (Dufek \& Ambrizzi, 2008; Espinoza et al., 2019; Haylock et al., 2006; Santos et al., 2012; Sugahara, 


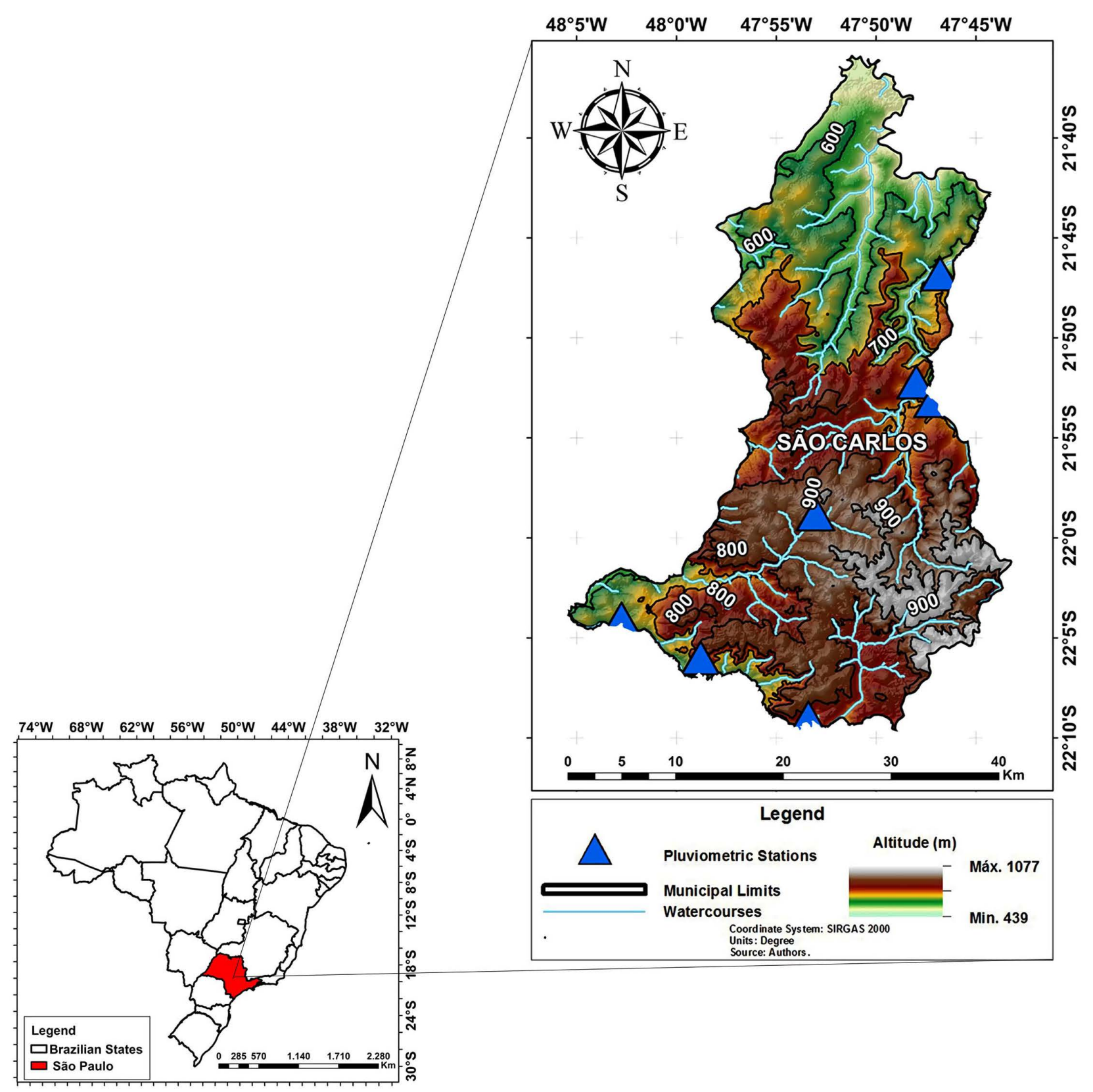

Figure 1. Localization of the pluviometric stations in São Carlos/SP. Source: adapted from the Brazilian Institute for Geography and Statistics (IBGE, 2009).

Rocha, \& Silveira, 2009), or parametric tests, such as the Chi-Square, Kolmogorov-Smirnov, and Wavelets tests, as well as the Student's t-test (Blain, 2011, 2013; Rao et al., 2016).

Regarding the mentioned methodologies, it is noteworthy to emphasize the importance of observing the temporal and spatial trends of rainfall using climatic indexes, in their volume and accumulated daily values (Dufek \& Ambrizzi, 2008; Haylock et al., 2006). Such analyses can be performed by correlating the rains and oceanic anomalies (Haylock et al., 2006; Santos et al., 2012; Sugahara, Rocha, \& Silveira, 2009; Vásquez et al., 2018; Zilli et al., 2017), and also by spatial 
data interpolation (from satellites and the surface) (Rao et al., 2016).

In the present study, the quality of the data was assessed individually between the stations, disregarding faulty data and organizing them into different tables to verify possible errors. The method known as the "Laplace Test", applied to observe the tendencies of annual rainfall values in the studied area, allows the identification of a trend in a set of data based on a value $u(t)$ considering a given pe$\operatorname{riod}(0, t]$, and is defined by the following equation (Kanoun, Martini, \& Souza, 1991):

$$
u(t)=\frac{\frac{\sum_{i=1}^{t}\left((i-1) n_{i}\right)}{N(t)}-\frac{(t-1)}{2}}{\sqrt{\frac{t^{2}-1}{12(N(t))}}}
$$

where $t$ represents the number of days (or another unit of time), $n_{i}$ the variable analyzed at time $i$ (daily rainfall value at the pluviometric stations), and $N(t)$ denotes the cumulative number regarding the analyzed variable (amount of rain accumulated up to the $t$-th day).

The practical interpretation of the Laplace Test is performed on two levels (CHRUN, 2011):

- Globally: when the Laplace coefficient values are higher than +2 or -2 . If the values are positive (negative), a global increase (decrease) occurs in the analyzed variable. Values between -2 and +2 indicate stability;

- Locally: values that increase (decrease) indicate a local increase (decrease) of the analyzed variable. It was considered local analysis, the moments in which the trend changed from an increase (decrease) to stability, from stability to decrease (increase). These periods were calculated individually for stations with the most consistent data.

Therefore, the proposed approach consists of examining the trend values of pluviometric data over a given period and identifying tendencies of global rainfall increase or decrease over such a period and, when appropriate, to analyze the trends locally. The Laplace test is commonly utilized in the literature to identify trends in different situations, such as: modeling software failures (Sukhwani et al., 2016; Yang et al., 2018), identifying trends in computer security vulnerabilities (Miani et al., 2015), and performing reliability analysis in engineering projects (Al-Chalabi et al., 2016; Chrun, 2011).

The Laplace trend statistics give a clear picture about the possible trends in a dataset. This could be applied in climatological studies, for example, by identifying trends and associating it to its occurrence, contextualizing the atmosphere of that moment. According to Gaudoin (1992) and Lehtinen, Pulkkinen and Pom (1997), the use of Laplace statistics is suitable to analyze any collection of points randomly located on some underlying mathematical space such as the real line or the Cartesian plane, which is our case. To the best of our knowledge, this is the first paper that uses the Laplace Trend Test for rainfall analysis. Be- 
sides, the tool's considerations, potentials, and weaknesses were described in the conclusions.

Figure 2 illustrates the application of the Laplace trend factor in a 52-week dataset. Values inside the +2 and -2 intervals represent global stability, while values outside such a range are related to a trend (increase or decrease).

For example, by examining Figure 2, it can be noted that there was a stability between weeks 1 and 22. After that, a globally declining trend was observed. To highlight the quantitative and temporal aspects of the rainfall dynamics, some basic statistics and a histogram including the normal distribution of daily rainfall were calculate as observed in Table 2 and Figure 3 and Figure 4.

\section{Results and Discussion}

The daily pluviometric data was organized into spreadsheets and treated individually, discarding faulty data, to establish quality control. Thus, calculations were performed without filling in the missing periods. Later, Laplace trend analysis was conducted for the historical series of the seven pluviometric stations by

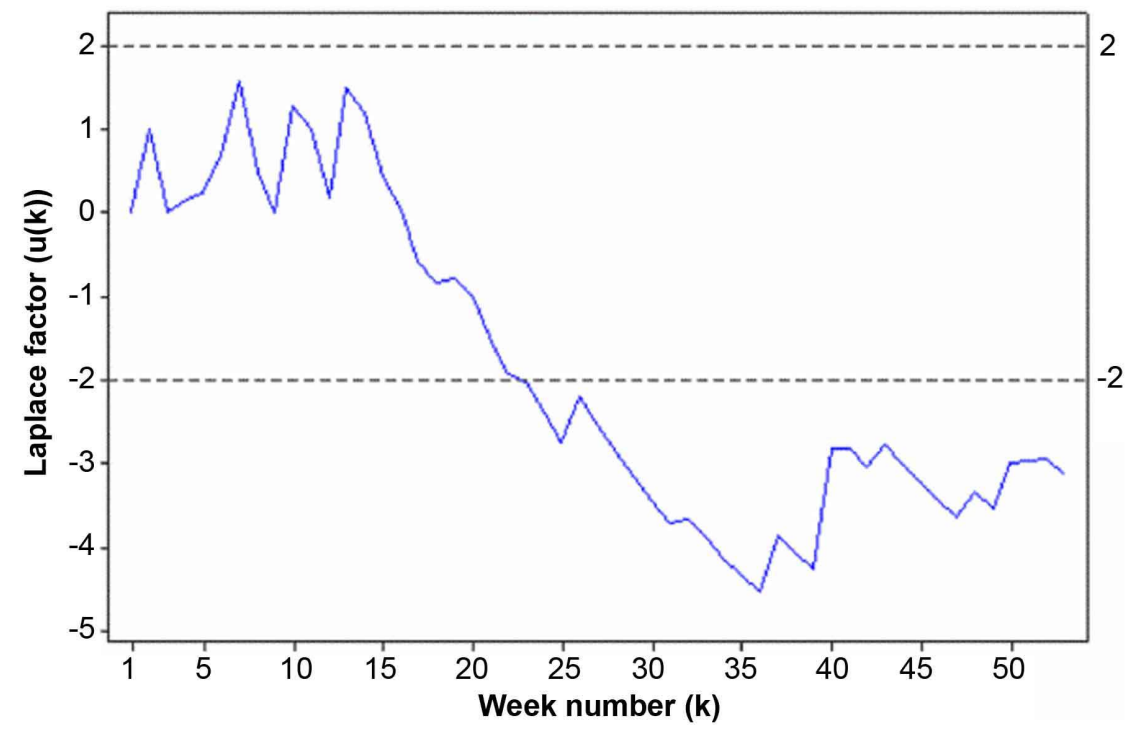

Figure 2. Laplace trend factor. Adapted from Miani et al. (2015).

Table 2. Description of the pluviometric stations in the São Carlos/SP region.

\begin{tabular}{cccccccc}
\hline Name station & Total & Mean & Desv. Pad. & Variance & Coeff. Var. & Amount & Q3 \\
\hline Santa Eudóxia & 3604 & 10.046 & 8.974 & 80.538 & 89.33 & $36,507.800$ & 15.700 \\
Santa Bárbara & 2726 & 12.707 & 9.380 & 87.990 & 73.82 & $34,640.300$ & 19.500 \\
Água Branca & 3407 & 9.807 & 9.292 & 86.348 & 94.75 & $33,412.300$ & 15.400 \\
Barra & 3490 & 9.970 & 9.017 & 81.301 & 90.44 & $34,794.000$ & 15.600 \\
Ribeirão Feijão & 4221 & 8.691 & 8.951 & 80.114 & 102.99 & $36,683.600$ & 13.500 \\
Capão Preto & 3250 & 9.837 & 9.042 & 81.759 & 91.92 & $31,968.900$ & 15.500 \\
UFSCar & 4047 & 8.961 & 9.011 & 81.191 & 100.56 & $36,478.800$ & 13.700 \\
\hline
\end{tabular}




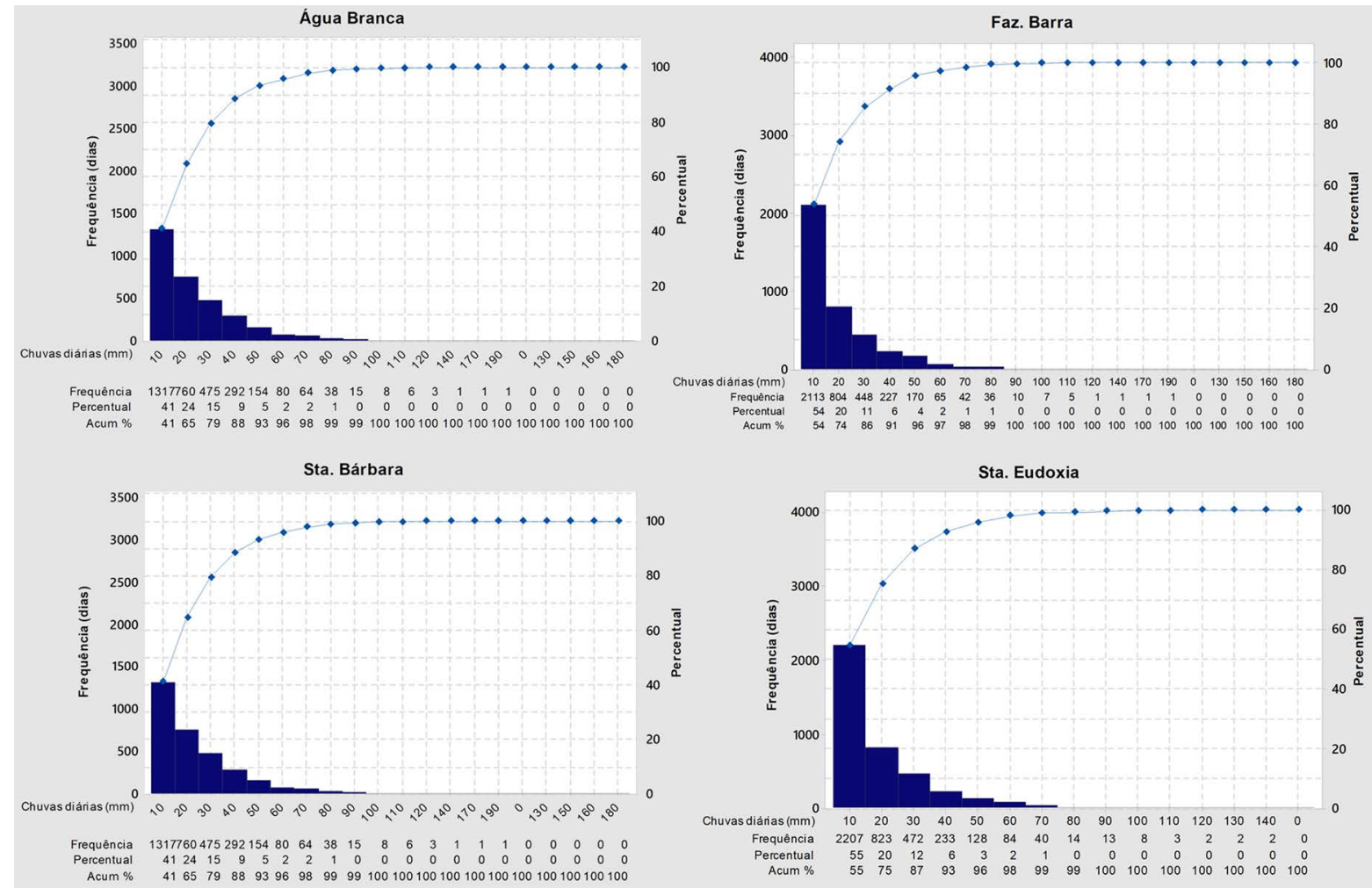

Figure 3. Frequency, cumulative frequency and cumulative percentage in the Água Branca, Faz. Barra, Sta. Bárbara; Sta. Eudoxia stations. Source: the authors.

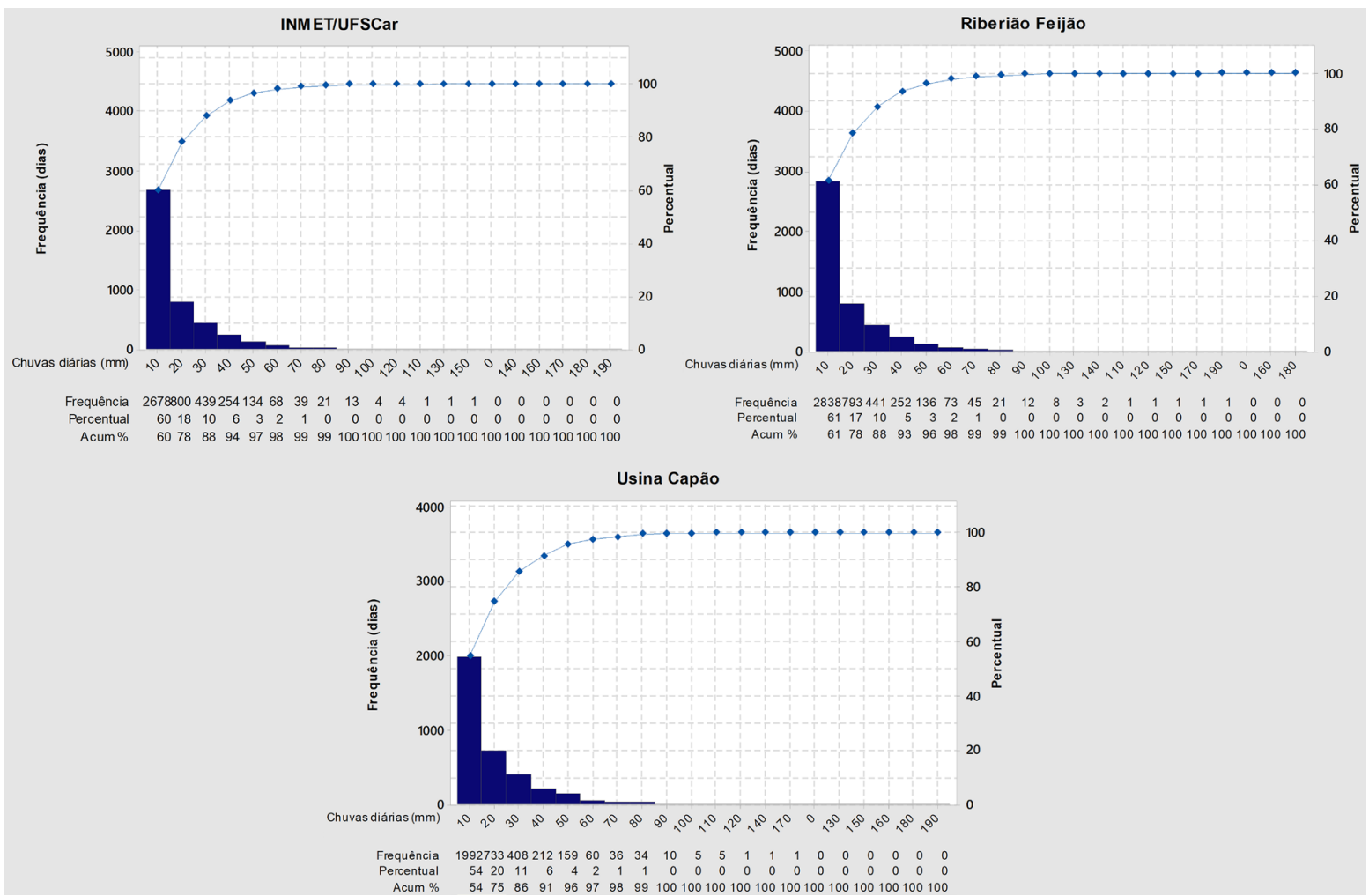

Figure 4. Frequency, cumulative frequency and cumulative percentage in the INMET/UFSCar, Ribeirão Feijão and Capão Preto stations. Source: the authors. 
arranging them separately into graphs to understand the local and regional aspects of the rainfall tendencies in São Carlos/SP city.

The discussion of the results was carried out according to the following:

- global rainfall analyses, i.e., for the entire historical series, considering all pluviometric stations combined;

- global analyses of rainfall in the pluviometric stations, individually (under the local climatic scale);

- local analysis of rainfall, in periods that comprehend the most positive (and negative) trends for the historical series, with emphasis in the pluviometric stations that presented greater data consistency.

It was verified a significant interannual fluctuation after calculating the rainfall tendencies for the region, which were more pronounced in the initial years of the adopted historical series (1979-1990). Since the 1990s, the behavior of the rainfall trends among the pluviometric stations deepened different spatial aspects and their disparities have been significant ever since. Quantitatively, the stations, displayed similar behavior.

It is worth mentioning that the global rainfall trends began to decline in 1987, and, as of the 1990s, most of the stations already exhibited negative tendencies regarding the volumes of rain, which intensified as of 1994. The trends for the period 1979-1984 showed to be the most significant considering the exponential increase in rainfall, as well as its abrupt change tending to decrease. This period represented great variability in rainfall volumes and in 1983 the highest value of the positive trends was observed.

Among the main reasons for such variability are the oceanic influences through teleconnections, in which the rainfall showed considerable interannual variations. These data coincide with the positive and negative phases (warming and cooling, respectively) of the oceans, particularly the Pacific, by the Pacific Decadal Oscillation (PDO) and Southeast Pacific Oscillation (SEPO) - El Niño and La Niña, respectively - as described by (Vásquez et al., 2018).

During 1982-1983, the most significant values of the positive trend (increase) for the historical series (and between the pluviometric stations) were recorded. The period was characterized by intensified rainfall in Southeast Brazil, which coincided with the El Niño, due to increments in the Ocean's surface temperature (Vásquez et al., 2018). The obtained results denote that, during 1979-1981 and 1984-1985, the rainfall showed a negative trend, coinciding with the negative tendency period for the La Niña phenomenon, due to the reduction in the Ocean's surface temperature (Vásquez et al., 2018).

The negative tendencies became expressive as of the 1990s, and only Ribeirão Feijão and Fazenda Água Branca pluviometric stations maintained a positive trend. Since the 2000s, only Ribeirão Feijão station has shown a normal or positive tendency. The period 2014-2015, however, showed to be the most expressive regarding the decreasing trend considering regional atmospheric characteristics. The interval included a prolonged drought and was classified as "dry," which contributed to the hydrological impacts in the region (Santos, Souza, \& Vecchia, 
2017). During the period, the reduction in rainfall trends was also associated with teleconnections, since, despite the Pacific's neutral phase, the PDO was undergoing a change between phases (negative to positive), which contributed to the decrease in rainfall volumes (Figure 5). In time, reducing trends for global rainfall values are also observed in the region of São Carlos/SP.

\subsection{Global Analysis of Pluviometric Trends in Stations, Individually}

This study analyzed the individual tendencies of the pluviometric stations due to the variability in rainfall trends observed between them. Barra pluviometric station was the first assessed site and presented the most significant data consistency and lowest number of errors. During the initial years of the series, the Laplace coefficient values remained around -20 , denoting the smallest value in the entire historical series. However, in the following years, an increase in global

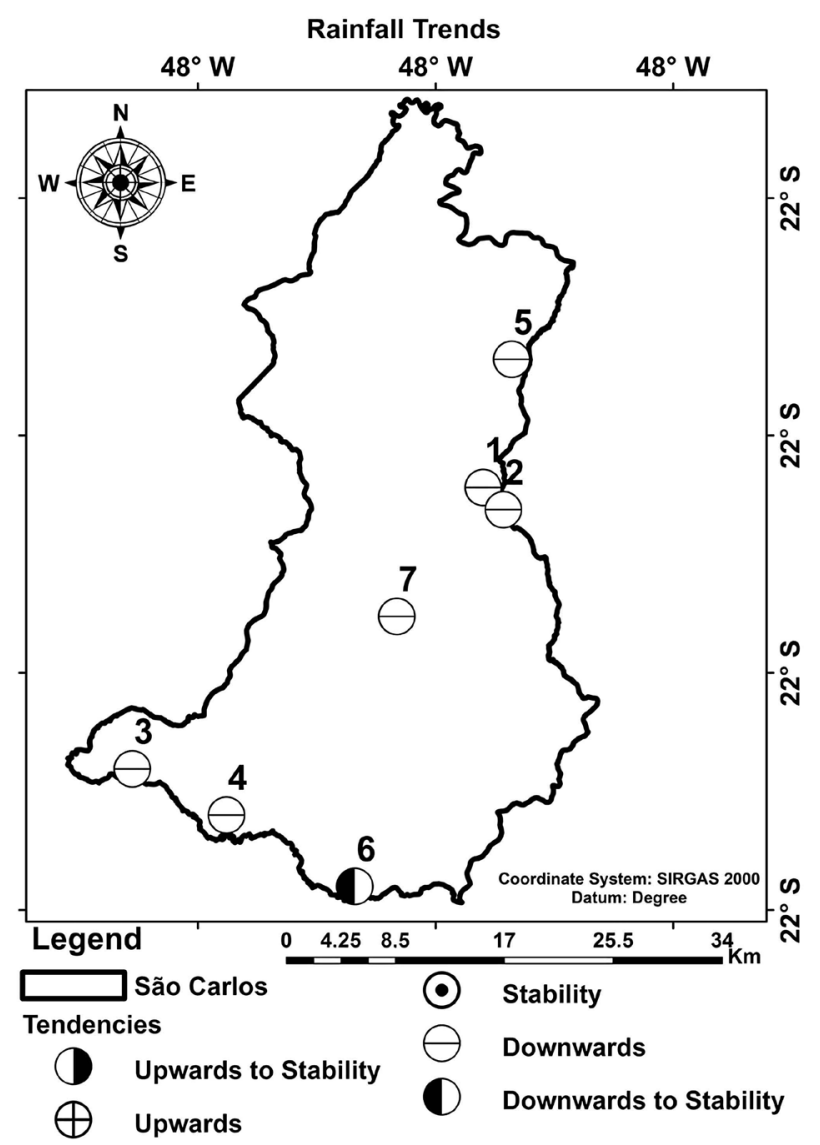

\begin{tabular}{|l|l|}
\hline \multicolumn{2}{|c|}{ Name (station) } \\
\hline 1- USINA CAPÃO PRETO & 5- SANTA EUDOXIA \\
\hline 2- FAZENDA DA BARRA & 6- INMET (UFSCar) \\
\hline 3- FAZENDA AGUA BRNCA & 7- RIBEIRÃO DO FEIJÃO \\
\hline 4- FAZENDA SANTA BÄRBARA & \multicolumn{1}{|l}{} \\
\cline { 1 - 2 } &
\end{tabular}

Figure 5. The global trends on their spatial distribution through the stations. 
rainfall trends was observed, evidenced in the period 1982-1983, as shown in Figure 6.

Despite fluctuations between drought periods and rainy seasons each year, approximately $52 \%$ of the series years were either positive or neutral. Thus, only ten years presented positive trends, representing around $26 \%$ of the series. Santa Eudoxia pluviometric station also showed similar behavior to the previous site. However, its longer lasting negative trends expressed a significant reduction in rainfall volume (Figure 7). Negative trends were also present in the early years of the series in the previously mentioned station, and only nine years of the series showed positive trends (approximately 23\% of the years).

In the period 1987-1991, the trends ranged from neutral (normal) to decrease. Since 1991, the rainfall values have declined each year, denoting a reducing tendency in rainfall volumes in this station as well, especially during 2006-2007 and

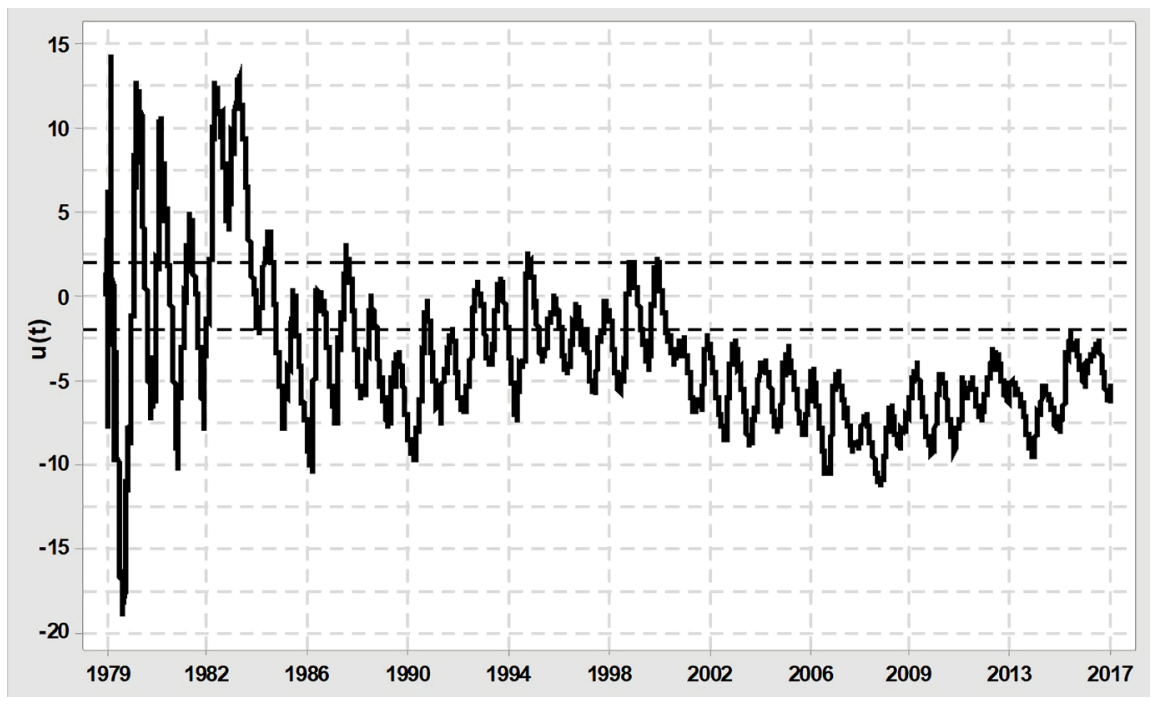

Figure 6. Laplace trend for the Fazenda da Barra station. 1979-2017. Source: the authors.

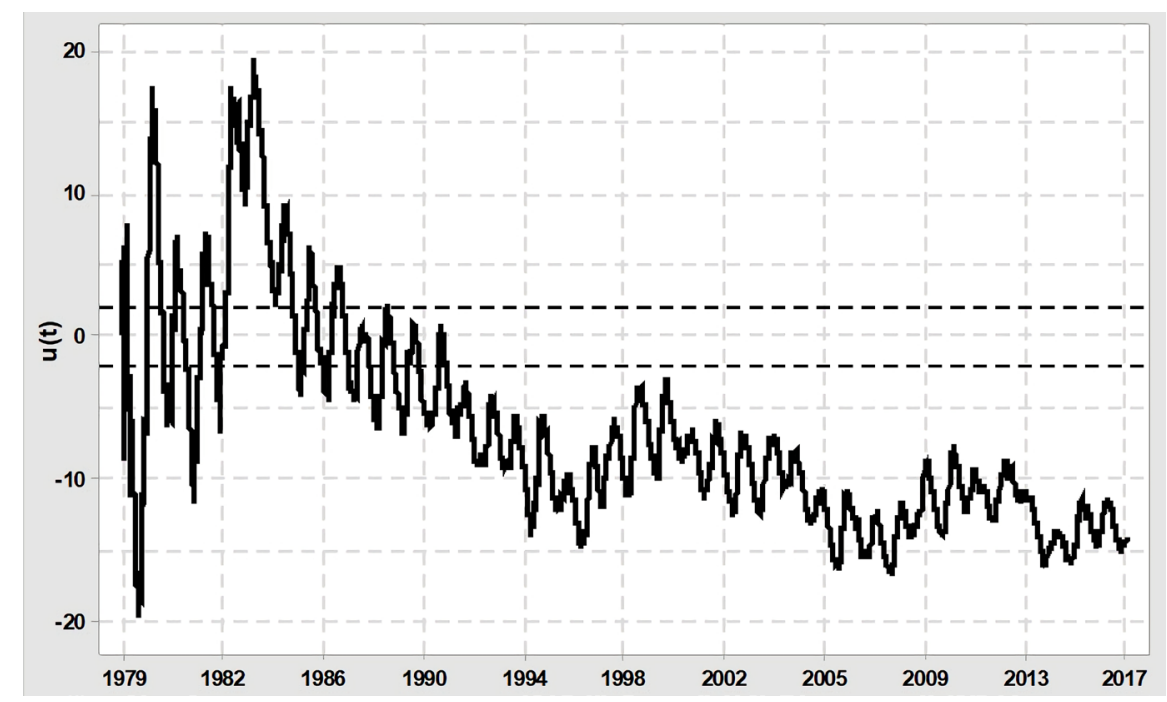

Figure 7. Laplace trend for the Fazenda da Barra station. 1979-2017. Source: the authors. 
2014-2015, with even lower trends. Fazenda Santa Bárbara pluviometric station exhibited similar characteristics to the other stations. However, the negative trends since 1992 showed even lower values of $u(t)$, which represented the lowest among the analyzed stations (Figure 8).

Merely 12 years of the series exhibited a normal or increasing trend, representing approximately $31 \%$ of the annual data. As of the 1990 s, the pluviometric tendencies indicated the reduction of annual rainfall, as observed in Table 3.

In the years 2008, 2014, and 2015, the negative trends became even more evident, reinforcing the earlier teleconnection analysis. On the other hand, Fazenda Água Branca pluviometric station registered fluctuations in trend values throughout the series, especially between 1985 and 2007. The period 1985-1995 expressed negative tendencies and/or values within normality (Figure 9).

The values observed in the period 1996-2007 exhibited an increasing or normal behavior, with an emphasis in the year 2000, which retained the highest positive trend for this station throughout the period 1985-2017. Nonetheless, as of 2007, a substantial irregularity in the behavior of rainfall trends was observed, and, from 2011 onward, the tendency was considerably negative (below -20). The period 2014-2015 was characterized as retaining the most significant negative trend in the entire analyzed data series. Despite some faulty years, the behavior of the rainfall trends in the INMET/UFSCar station was similar to the others, especially in the period 1982-1984, in which the values were more positive, globally, regarding the increment in pluviometric volumes (Figure 10).

Table 3. Description of the trend data for the Fazenda Santa Bárbara station. Source: the authors.

\begin{tabular}{cc}
\hline & Rainfall trends - Fazenda Santa Bárbara Station \\
\hline $1979-1987$ & Normal and/or Increasing \\
$1988-1991$ & Normal and/or Increasing \\
$1992-2017$ & Decreasing (more evident in 2008. 2014. and 2015) \\
\hline
\end{tabular}

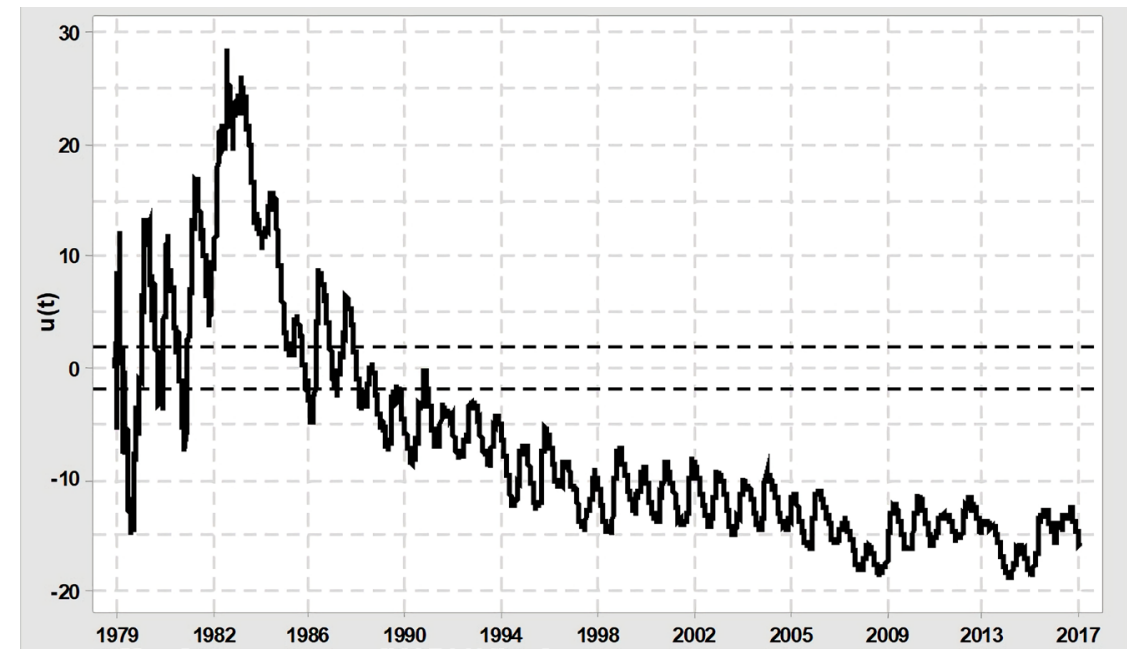

Figure 8. Laplace trend for the Fazenda Santa Bárbara station. 1979-2017. Source: the authors. 


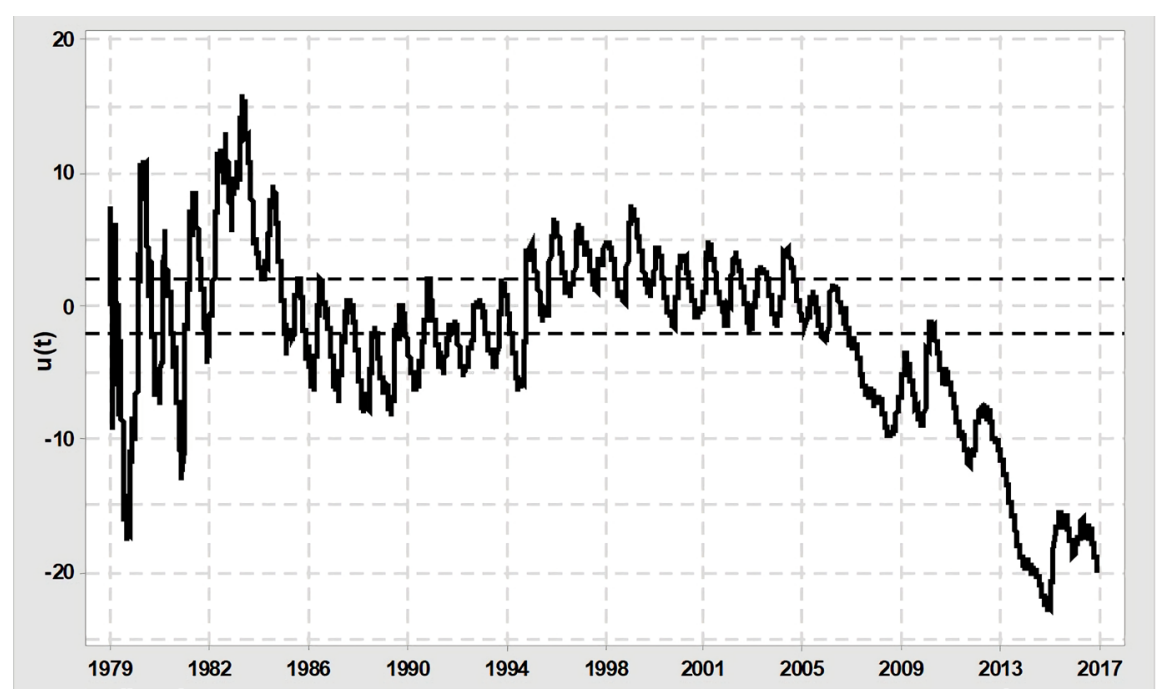

Figure 9. Laplace trend for the Água Branca station. 1979-2017. Source: the authors.

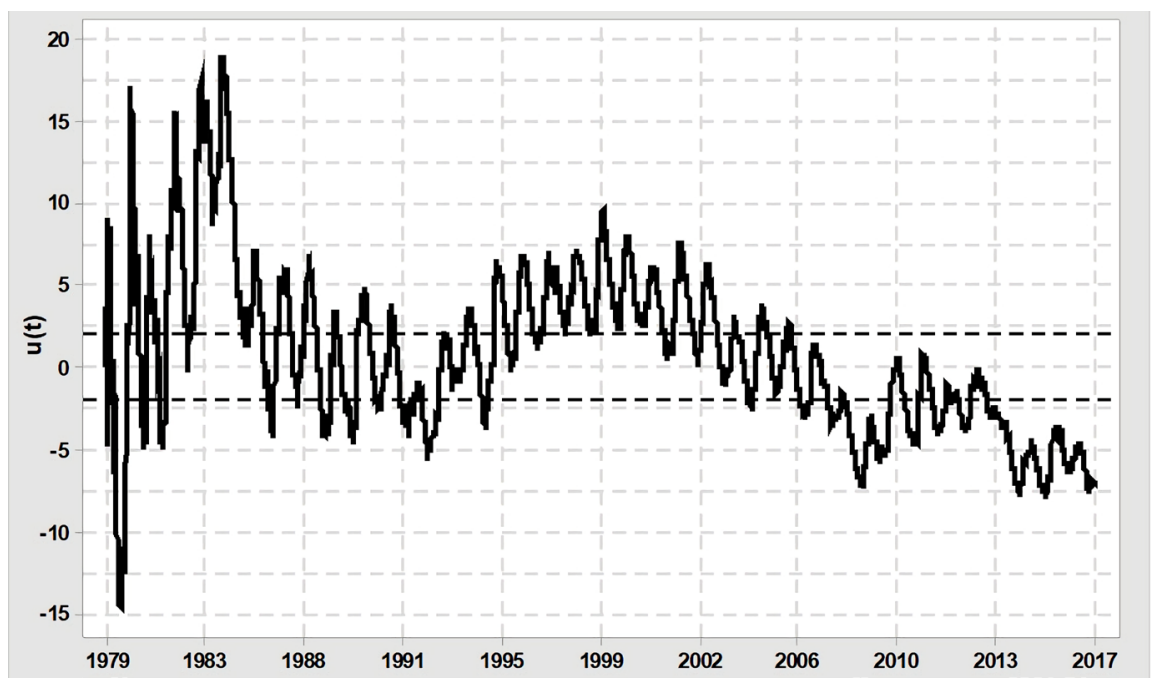

Figure 10. Laplace trend for the INMET/UFSCar station. 1979-2017. Source: the authors.

Also, it is noteworthy that the interval 1992-2006 showed positive or normal values considering the rainfall trend, and, as observed in other stations in the region, it was possible to verify a decreasing tendency in rainfall during the last years.

During the period 2013-2017, the negative values evidenced the common characteristic between the INMET pluviometric station and the other five stations, denoting a reduction of rainfall volume in recent years, regardless of their annual seasonality.

The other two analyzed pluviometric stations did not present the same temporal delimitation. Ribeirão Feijão station had data recorded up to 2016, while Capão Preto station presented data until 2014. Nevertheless, in order to ascribe greater robustness to their spatial character, both of the last stations underwent calculation. As a result, Ribeirão Feijão station was the only one that exhibited data normality in most of the series years (Figure 11). 


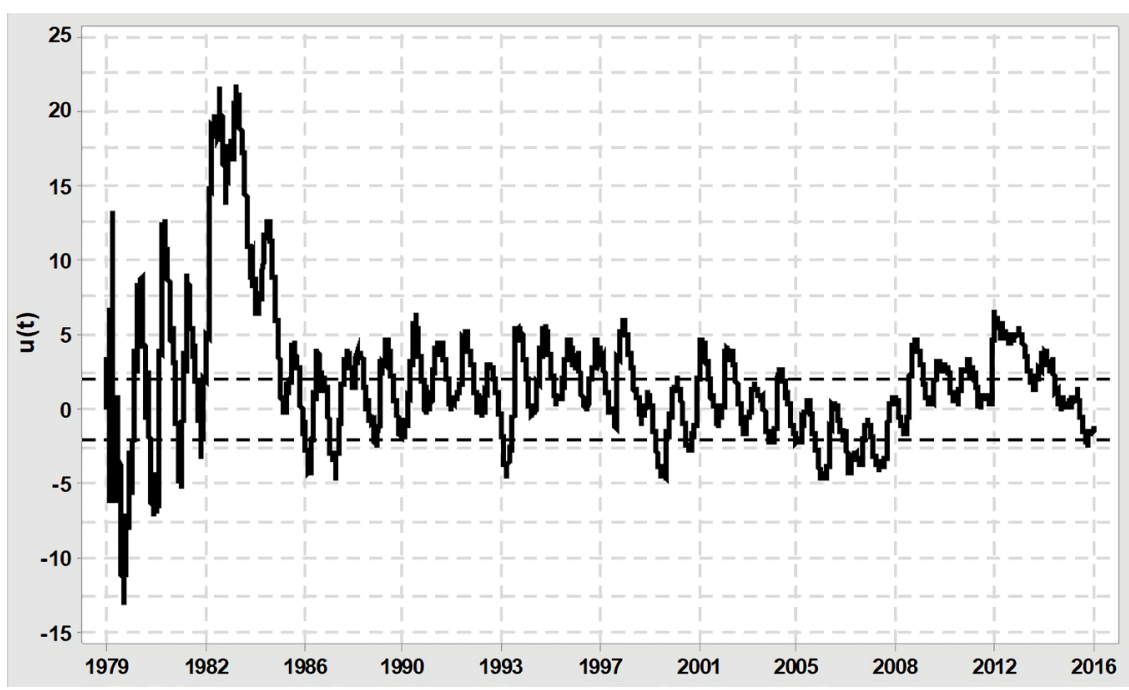

Figure 11. Laplace trend for the Ribeirão Feijão station. 1979-2016. Source: the authors.

Also, the period 1982-1985 showed positive trends for increases in rainfall. Since Ribeirão Feijão station was the only one that conveyed such continuity, it represents one of the most complex in the group. During the period 2008-2016, Ribeirão Feijão station remained uniquely neutral and/or increased regarding rainfall trends, contrasting locally with the other stations. Nonetheless, the objective herein was not to understand which local effect contributed to such a characteristic, such regional feature could be justified by the elevation effect of the region (microscale) and possibly the valley bottom effect where the station is located.

Capão Preto pluviometric station was the only one that did not present adequate daily rainfall values for the total historical series. However, despite retaining consistent data only up to 2014, such a fact did not imply any extensive loss of data. The mentioned station presented a significant oscillating behavior during the initial calculated years (1979-1984). Nevertheless, the other pluviometric stations recorded positive trend values within the period, as shown in Figure 12.

Moreover, between 1985 and 2000, the fluctuations between normal trending values and negative tending years reinforce the context of greater consistency and lower rainfall variability, as previously described for all the other pluviometric stations. During the period 2001-2014, the authors verified negative tendency values regarding the pluviometric data, characterizing a decreasing trend in rainfall values for the last observed years at the station. It is noteworthy that the year 2014 did not present lower value regarding the negative trend (as in the other stations). In turn, the values obtained during that year indicate a decrease in accumulated rainfall for the region.

\subsection{Local Analyses of the Most Consistent Stations}

The local analyses express the trends for periods of years in which the rains showed more substantial values of increasing or decreasing tendency throughout the adopted series. 


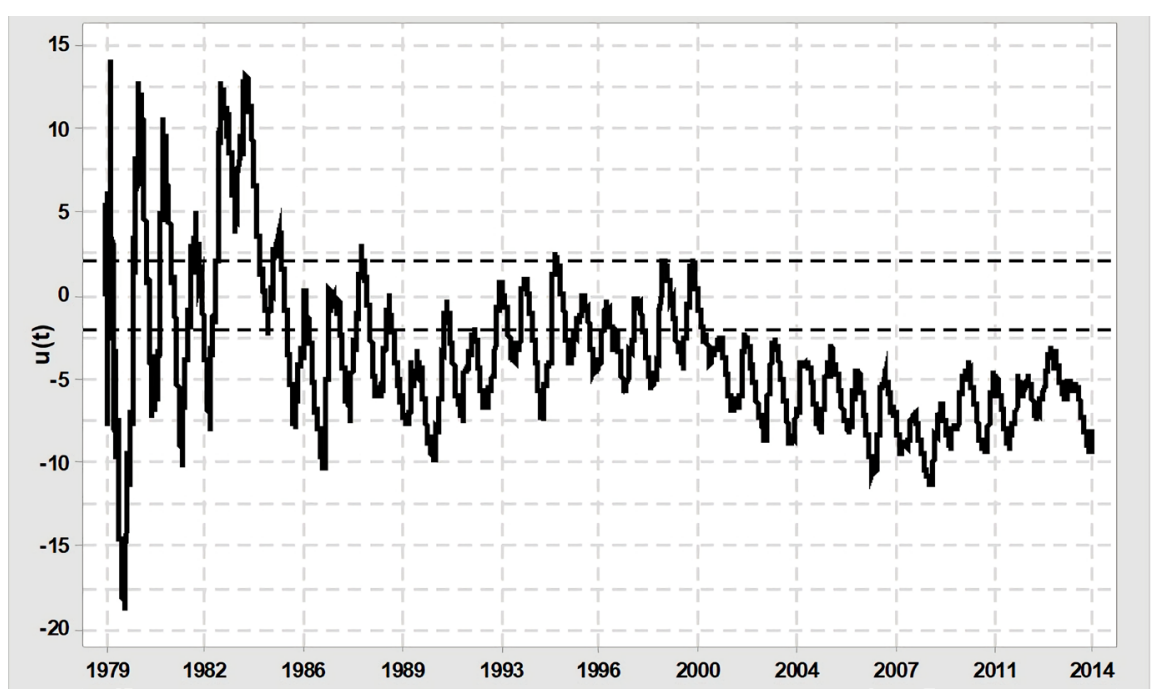

Figure 12. Laplace trend for the Capão Preto station. 1979-2014. Source: the authors.

The stations were selected according to the criterion of greater data quality (fewer errors) and:

- presented the most pronounced negative trends, in which Barra station was chosen;

- with only positive trends in the data series, in which Ribeirão Feijão station was chosen.

Local analysis was calculated individually in the intervals of the periods in which trends were changed in time series (downwards to stability, stability to upwards, for example). The local data analysis of Fazenda da Barra station was organized in three periods: 1979-1985, a period characterized by upward global trends; 1986-2001, a period of greater fluctuation between years with normal or negative tendencies; 2002-2017, a period presenting a continuous negative trend.

Substantial fluctuations in data were verified in the period 1979-1985. However, the most significant positive trend volume was concentrated in 1983, the rainiest period of the data series, in all seasons, justifying previous observations (Figure 13).

The fluctuations in other years can be explained by the seasonal nature of the region climate, in which a period of rainfall (hydrological period) and drought are observed (Santos, Souza, \& Vecchia, 2017). Despite this fact, locally, there are increasing trends in rainfall for the period. The most considerable fluctuation in global trend data was observed in the period 1986-2001. The most significant oscillations of the local analysis were recorded up to 1989 , denoting the continuity of occurrences in previous years, as observed in Figure 14.

However, from 1990 to 2000, the fluctuating behavior of the data showed to be within normality, that is, the series contained rainy periods with positive trend values and drought periods with negative trend values, evidencing the natural seasonality of the region's climate. During the period 2000-2001, regardless of seasonality, reducing trends of pluviometric volumes were observed. The last years of the series presented a different behavior regarding the global analyses. 


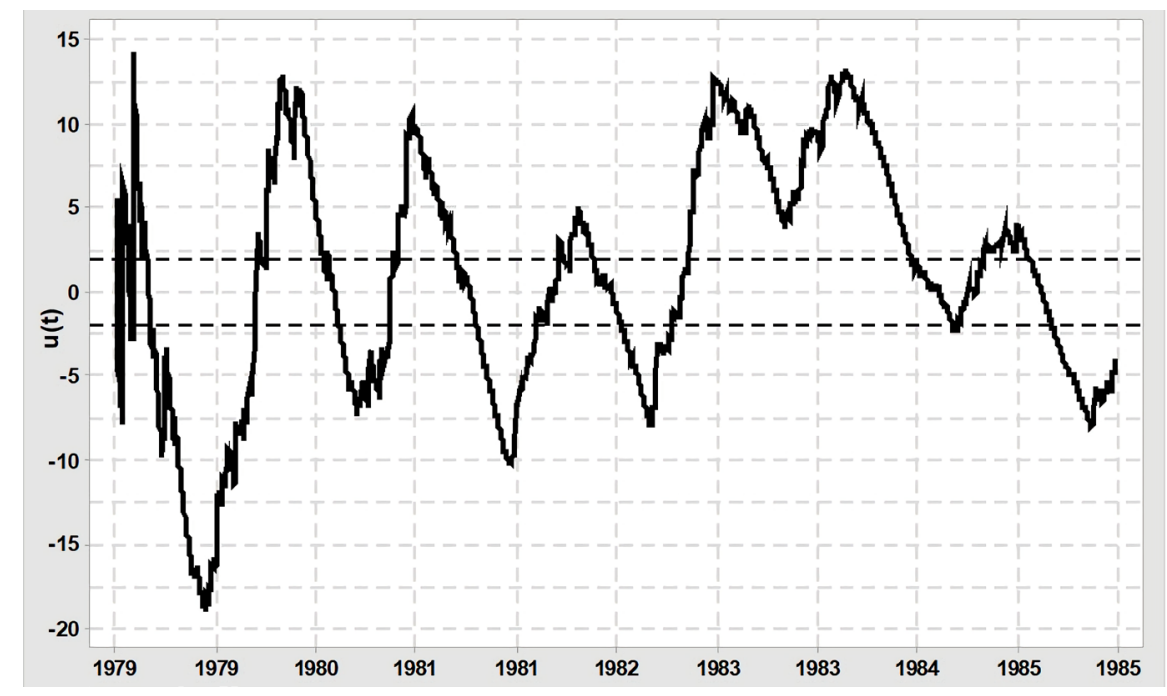

Figure 13. Local analysis of the Laplace trend for the Barra station. 1979-1985. Source: the authors.

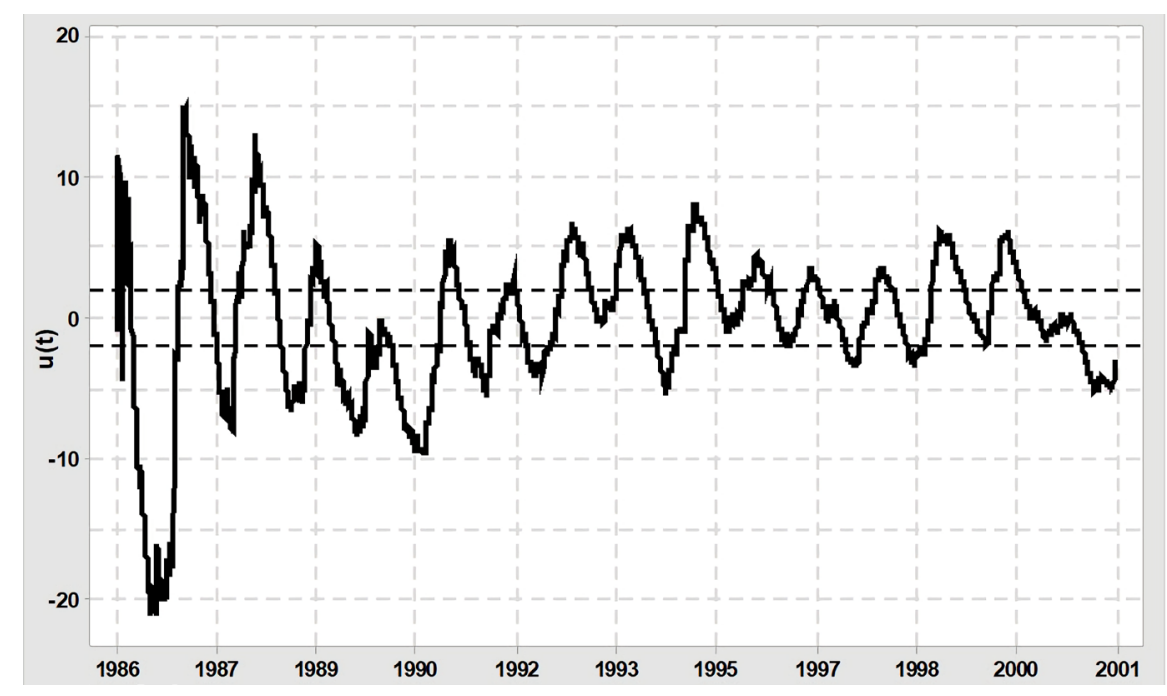

Figure 14. Local analysis of the Laplace trend for the Fazenda da Barra station. 1986-2001. Source: the authors.

Despite deep oscillations in the years 2002-2004, the trends were positive considering climatic seasonality (Figure 15).

These elements represent normal trend values during the final years of the adopted data series. In the year 2014, as discussed previously, a negative trend for rainfall was verified. However, from 2015 to 2017, local rainfall tendencies pointed to positive values and/or within the expected thresholds. Thus, it can be inferred that, in the joint data analysis (global analysis), the trends tended towards a reduction in pluviometric volumes. Nonetheless, the detached observation of the periods indicates that the "dry" years, which present negative tendencies, showed normal behavior. The authors conducted two periods of local analysis for Ribeirão Feijão station: 1979-1985, with the most significant positive trends; 1986-2016, with fluctuations that were closer to normality or positive. 


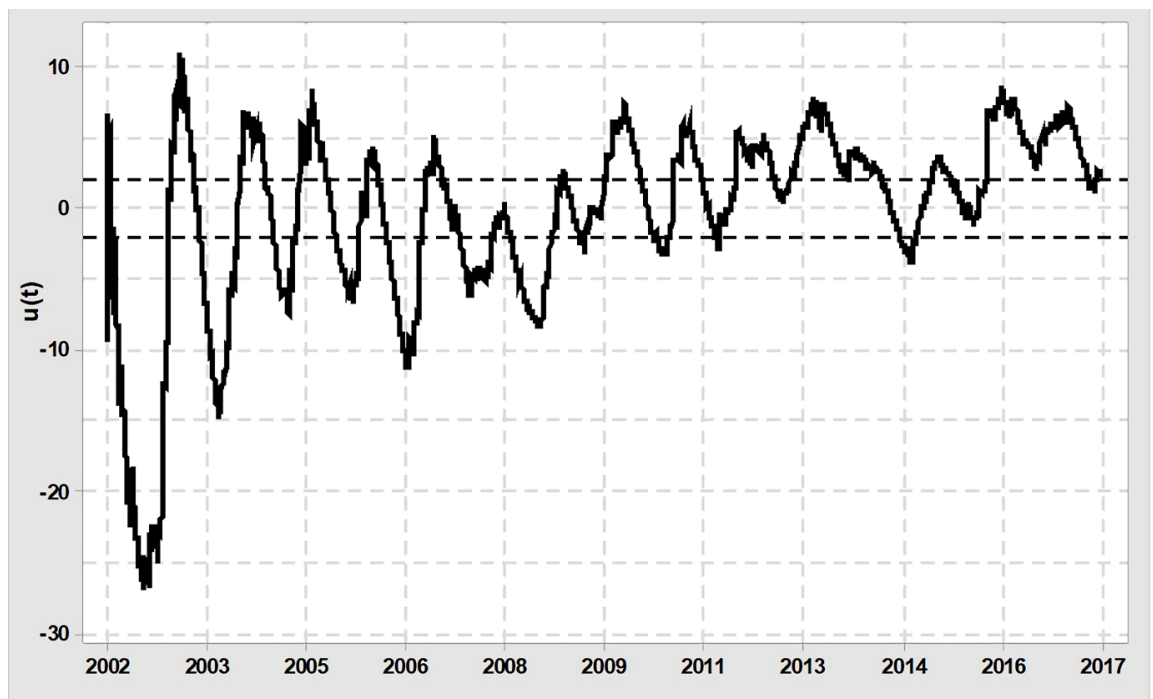

Figure 15. Local analysis of the Laplace trend for the Fazenda da Barra station. 2002-2017. Source: the authors.

The annual and interannual fluctuations in the period 1979-1985 presented positive trends, with 1983 being the most typical year due to its substantial rainfall values, which continued until the hydrological period of 1985, when seasonality pointed to decreasing tendencies (Figure 16).

In the first period, notable fluctuations were observed, since the seasonality represented exceptional values regarding the rainy season due to its tendency, followed by an abrupt decrease in trend values for the drought period. The period 1986-2016, however, showed fluctuations within normality in most years or with positive trends towards an increase in rainfall (Figure 17).

Such statements are evident since only six years presented values with negative tendencies in the interval, representing $20 \%$ of the period. Also, from 2013-2016, a distinct behavior from the other pluviometric stations was noted, inferring different local climatic behavior. The authors herein did not verify, by other means, what would implicate in such an increase in pluviometric values.

However, according to the geomorphological and hydrological character of the region, it is probably associated with the "bottom-of-valley" phenomenon, a prominent occurrence in the microclimatic (and even mesoclimatic) aspect, which implies significant thermal and pluviometric variability, as well as its correlation with convective phenomena (Amorim, 2004; Martins, 2014; Sharon \& Kutiel, 1986).

The observation of trends in rainfall through historical data is of considerable value, together with the interpretation of its temporal and spatial behavior. Thus, the chosen method (Laplace test) showed to be effective in annually guiding the rainfall distribution in climatological seasons.

\section{Conclusions}

Considering these aspects, the present study verified the temporal behavior of 


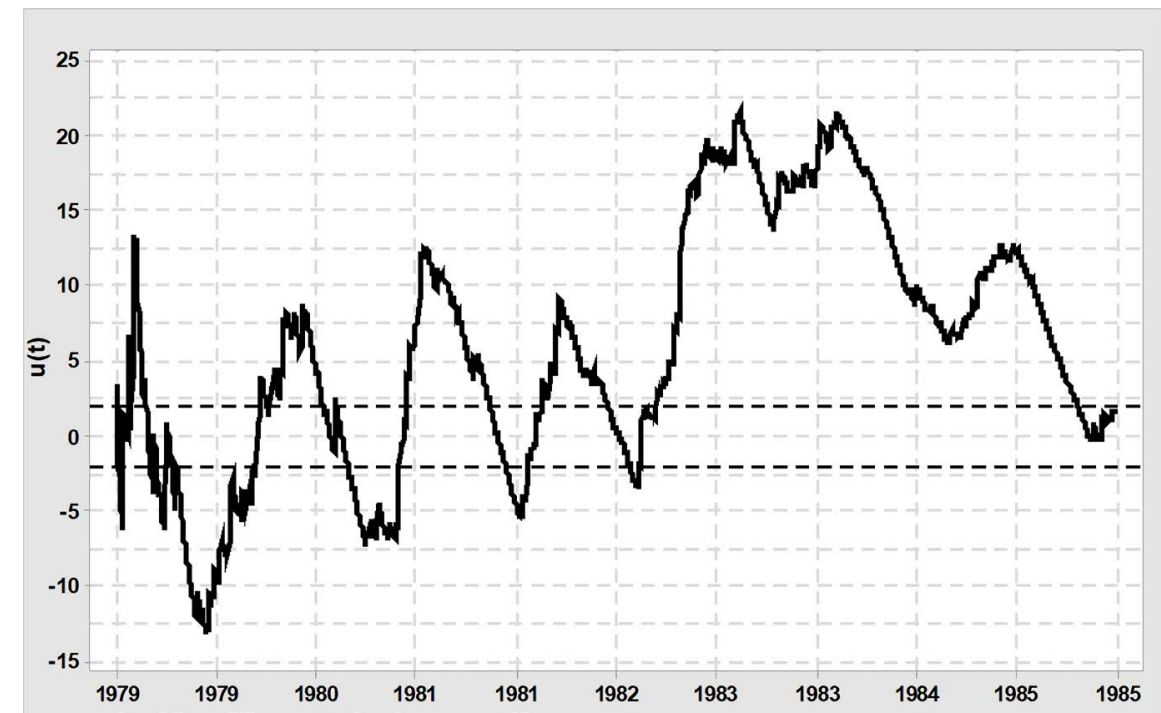

Figure 16. Local analysis of the Laplace trend for the Ribeirão Feijão station. 1979-1985. Source: the authors.

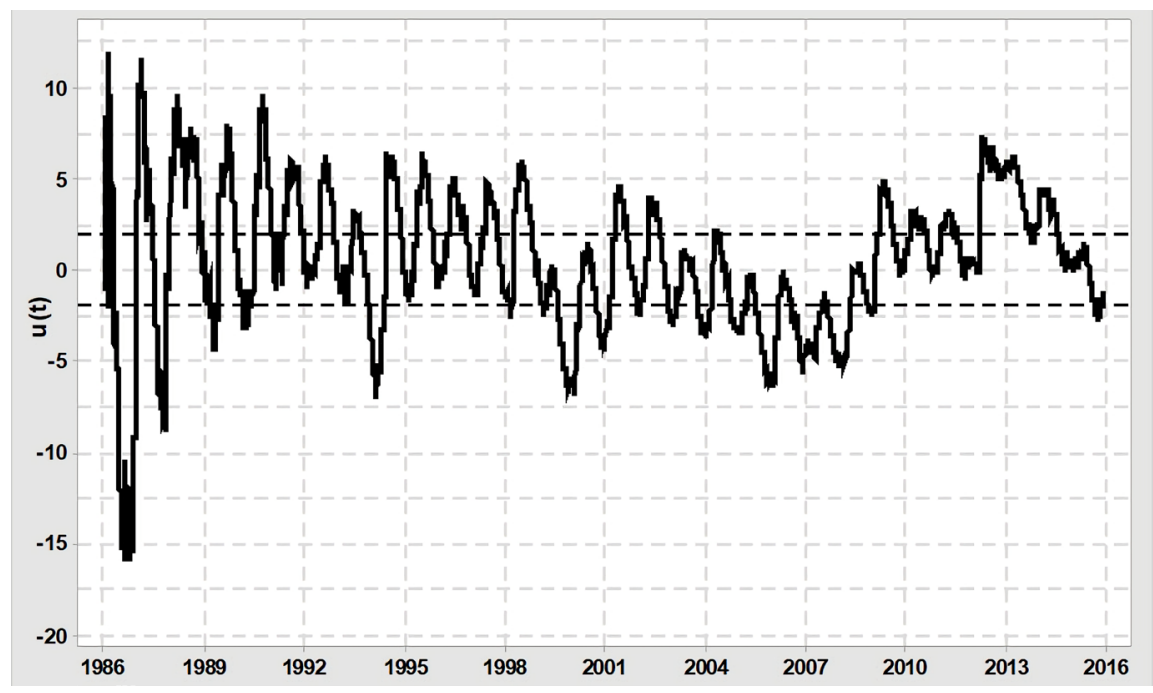

Figure 17. Local analysis of the Laplace trend for the Ribeirão Feijão station. 1986-2016. Source: the authors.

rainfall in São Carlos/SP in order to interpret the pluviometric trends for the region, since discussions regarding its intensification have shown to be of great interest in regional climatology.

The observed pluviometric values from São Carlos/SP region exhibited a reduction trend. In addition, the study is important, because it uses daily rainfall data and is treated on a local spatial scale (a micro region in the state). Such reduction, however, exhibited considerable variability in the 1980s, evidencing the region's macroclimatic influence on rainfall. Laplace test is often used by computer sciences, information technology and engineering.

This method is efficient to predict or anticipate the cumulative rainfall over the years (allied by growth data from stations) or to analyze the probability re- 
currence for policy makers. Additionally, the test does not exclude the use of other tools, such as neural networks or data mining, but can incorporate patterns and estimates of rainfall. Such limitations and the lack of studies in the environmental area do not undermine the potentiality of this method. This method proved to be an effective tool in identifying the pluviometric trends in long and heterogeneous data series. Therefore, such a tool can subsidize new studies for its validation as a technique in climatology, since it expresses a different mechanism for the identification of climatic trends. Therefore, by considering the daily rainfall data in a broad historical series, the trends registered in a behavior closer to the real one.

The present study also considers the test as a new methodology to detect trends in rainfall, without neglecting the importance of other techniques already validated in this type of assessment. In addition, the increment in the number of stations can improve the regional aspect and confirm or refute the results obtained by this paper. Future studies can, therefore, observe rainfall trends in different regions or even in other types of pluviometric events, such as extreme rains.

\section{Acknowledgements}

This study was financed in part by the Coordenação de Aperfeiçoamento de Pessoal de Nível Superior - Brasil (CAPES) - Finance Code 001. The following Brazilian institutions provided the individual station data: Agência Nacional de Águas (ANA); Instituto Nacional de Meteorologia (INMET), and Centro de Recursos Hídricos e Estudos Ambientais (CRHEA/EESC/USP). The authors thank the University of São Paulo and Federal University of São Carlos for their support.

\section{Conflicts of Interest}

The authors declare no conflicts of interest regarding the publication of this paper.

\section{References}

Al-Chalabi, H., Hoseinie, H., \& Lundberg, J. (2016). Monte Carlo Reliability Simulation of Underground Mining Drilling Rig. In Current Trends in Reliability, Availability, Maintainability, and Safety (pp. 633-643). Cham: Springer. https://doi.org/10.1007/978-3-319-23597-4_46

Amorim, L. M. (2004). Ocupação de fundos de vale em áreas urbanas. Estudo de caso: Córrego do Mineirinho, São Carlos, SP. Dissertação (Mestrado em Ciências Exatas e da Terra), São Carlos: Universidade Federal de São Carlos. https://repositorio.ufscar.br/handle/ufscar/4222

Blain, G. C. (2011). Totais decendiais de precipitação pluvial em Campinas, SP: Persistência temporal, periodicidades e tendências climáticas. Ciência Rural, 41, 789-795. https://doi.org/10.1590/S0103-84782011005000048

Blain, G. C. (2013). Seasonal Variability of Maximum Daily Rainfall in Campinas, State of Sao Paulo, Brazil: Trends, Periodicities, and Associated Probabilities. Acta Scientiarum. 
Technology, 35, 557. https://doi.org/10.4025/actascitechnol.v35i3.16222

Carvalho, L. M. V., Jones, C., \& Liebmann, B. (2004). The South Atlantic Convergence Zone: Intensity, Form, Persistence, and Relationships with Intraseasonal to Interannual Activity and Extreme Rainfall. Journal of Climate, 17, 88-108. https://doi.org/10.1175/1520-0442(2004)017<0088:TSACZI >2.0.CO;2

Cavalcanti, I. F. (2012). A. Large Scale and Synoptic Features Associated with Extreme Precipitation over South America: A Review and Case Studies for the First Decade of the 21st Century. Atmospheric Research, 118, 27-40. https://doi.org/10.1016/j.atmosres.2012.06.012

Chrun, D. (2011). Model-Based Support for Information Technology Security Decision Making. Dissertation, College Park, MD: University of Maryland. http://hdl.handle.net/1903/11555

Drumond, A. R. M., \& Ambrizzi, T. (2008). The Role of the South Indian and Pacific Oceans in South American Monsoon Variability. Theoretical and Applied Climatology, 94, 125-137. https://doi.org/10.1007/s00704-007-0358-5

Dufek, A. S., \& Ambrizzi, T. (2008). Precipitation Variability in São Paulo State, Brazil. Theoretical and Applied Climatology, 93, 167-178. https://doi.org/10.1007/s00704-007-0348-7

Espinoza, J. C. et al. (2019). Contrasting North-South Changes in Amazon Wet-Day and Dry-Day Frequency and Related Atmospheric Features (1981-2017). Climate Dynamics, 52, 5413-5430. https://doi.org/10.1007/s00382-018-4462-2

Evangelista, H. et al. (2007). Evidences Linking ENSO and Coral Growth in the Southwestern-South Atlantic. Climate Dynamics, 29, 869-880. https://doi.org/10.1007/s00382-007-0271-8

Gaudoin, O. (1992). Optimal Properties of the Laplace Trend Test for Soft-Reliability Models. IEEE Transactions on Reliability, 41, 525-532. https://doi.org/10.1109/24.249579

Haylock, M. R. et al. (2006). Trends in Total and Extreme South American Rainfall in 1960-2000 and Links with Sea Surface Temperature. Journal of Climate, 19, 1490-1512. https://doi.org/10.1175/JCLI3695.1

Kanoun, K., Martini, M. R. B., \& Souza, J. M. (1991). A Method for Software Reliability Analysis and Prediction Application to the TROPICO-R Switching System. IEEE Transactions on Software Engineering, 17, 334-344. https://doi.org/10.1109/32.90433

Kayano, M. T., \& Andreoli, R. V. (2007). Relations of South American Summer Rainfall Interannual Variations with the Pacific Decadal Oscillation. International Journal of Climatology, 27, 531-540. https://doi.org/10.1002/joc.1417

Kayano, M. T., \& Capistrano, V. B. (2014). How the Atlantic Multidecadal Oscillation (AMO) Modifies the ENSO Influence on the South American Rainfall. International Journal of Climatology, 34, 162-178. https://doi.org/10.1002/joc.3674

Kayano, M. T., De Oliveira, C. P., \& Andreoli, R. V. (2009). Interannual Relations between South American Rainfall and Tropical Sea Surface Temperature Anomalies before and after 1976. International Journal of Climatology, 29, 1439-1448.

https://doi.org/10.1002/joc.1824

Lehtinen, E. et al. (1997). Statistical Trend Analysis Methods for Temporal Phenomena. SKI Report-Swedish Nuclear Power Inspectorate, 97, 732-598.

Liebmann, B., Jones, C., \& De Carvalho, L. M. V. (2001). Interannual Variability of Daily Extreme Precipitation Events in the State of São Paulo, Brazil. Journal of Climate, 14, 208-218. https://doi.org/10.1175/1520-0442(2001)014<0208:IVODEP>2.0.CO;2

Lima, K. C., Satyamury, P., \& Fernández, J. P. R. (2010). Large-Scale Atmospheric Condi- 
tions Associated with Heavy Rainfall Episodes in Southeast Brazil. Theoretical and Applied Climatology, 101, 121-135. https://doi.org/10.1007/s00704-009-0207-9

Marengo, J. A. et al. (2010). An Intercomparison of Observed and Simulated Extreme Rainfall and Temperature Events during the Last Half of the Twentieth Century: Part 2: Historical Trends. Climatic Change, 98, 509-529. https://doi.org/10.1007/s10584-009-9743-7

Martins, L. F. V. (2014). Monitoramento de parques urbanos em fundos de vale: Análise das funções de conservação e uso público-estudos de casos múltiplos em Curitiba, Paraná. Thesis, São Paulo: Faculdade de Filosofia, Letras e Ciências Humanas, Universidade de São Paulo.

Miani, R. S. et al. (2015). A Practical Experience on Evaluating Intrusion Prevention System Event Data as Indicators of Security Issues. In: 2015 IEEE 34th Symposium on Reliable Distributed Systems (SRDS) (pp. 296-305). Montreal.

Muza, M. N. et al. (2009). Intraseasonal and Interannual Variability of Extreme Dry and Wet Events over Southeastern South America and the Subtropical Atlantic during Austral Summer. Journal of Climate, 22, 1682-1699. https://doi.org/10.1175/2008JCLI2257.1

Pscheidt, I., \& Grimm, A. M. (2009). Frequency of Extreme Rainfall Events in Southern Brazil Modulated by Interannual and Interdecadal Variability. International Journal of Climatology, 29, 1988-2011. https://doi.org/10.1002/joc.1799

Rao, V. B. et al. (2016). An Update on the Rainfall Characteristics of Brazil: Seasonal Variations and Trends in 1979-2011. International Journal of Climatology, 36, 291-302. https://doi.org/10.1002/joc.4345

Sanches, R. G. et al. (2018). Intense Rainfall in São Carlos/SP: Determination of Threshold Values Using Climate Indices and Their Spatio-Temporal Repercussion. American Journal of Climate Change, 7, 388. https://doi.org/10.4236/ajcc.2018.73023

Sant'Anna Neto, J. L., \& Zavattini, J. L. (2000). Variabilidade e Mudanças Climáticas: implicações ambientais e sócioeconômicas (1.Ed., Vol. 1, p. 259). Maringá: EdUEM.

Santos, B. C., Souza, P. H., \& Vecchia, F. A. S. (2017). The Characterization of the Precipitation in the 2013-2014 Hydrological Year in the Region of Sao Carlos-SP and Its Repercussion in the Geographical Space. Revista Brasileira de Climatologia, 21, 135-152. https://doi.org/10.5380/abclima.v21i0.51505

Santos, C. A. C., Satyamurty, P., Gomes, O. M., Silva, A. et al. (2012). Variability of Extreme Climate Indices at Rio Claro, São Paulo, Brazil. Revista Brasileira de Meteorologia, 27, 395-400. https://doi.org/10.1590/S0102-77862012000400003

Serra, Y. L. et al. (2014). Tropical Intraseasonal Modes of the Atmosphere. Annual Review of Environment and Resources, 39, 189-215. https://doi.org/10.1146/annurev-environ-020413-134219

Sharon, D., \& Kutiel, H. (1986). The Distribution of Rainfall Intensity in Israel, Its Regional and Seasonal Variations and Its Climatological Evaluation. Journal of Climatology, 6, 277-291. https://doi.org/10.1002/joc.3370060304

Silva Dias, M. A. F. et al. (2013). Changes in Extreme Daily Rainfall for São Paulo, Brazil. Climatic Change, 116, 705-722. https://doi.org/10.1007/s10584-012-0504-7

Sugahara, S., Rocha, R. P., \& Silveira, R. (2009). Non-Stationary Frequency Analysis of Extreme Daily Rainfall in Sao Paulo, Brazil. International Journal of Climatology, 29, 1339-1349. https://doi.org/10.1002/joc.1760

Sukhwani, H. et al. (2016). Software Reliability Analysis of NASA Space Flight Software: A Practical Experience. 2016 IEEE International Conference on Software Quality, Re- 
liability and Security (QRS) (pp. 386-397). Vienna. https://doi.org/10.1109/QRS.2016.50

Tolentino, M. (2007). Estudo crítico sobre o clima da região de São Carlos (76 p). São Carlos: EdUFSCar, São Paulo: Imprensa Oficial do Estado de São Paulo.

Vásquez, P. I. L. et al. (2018). Historical Analysis of Interannual Rainfall Variability and Trends in Southeastern Brazil Based on Observational and Remotely Sensed Data. Climate Dynamics, 50, 801-824. https://doi.org/10.1007/s00382-017-3642-9

Yang, T. J. et al. (2018). The Analysis and Predict of Software Failure Time Based on Nonlinear Regression. Journal of Engineering and Applied Sciences, 13, 4376-4380.

Youlton, C. et al. (2012). Influencia del fenómeno El Niño-La Niña y cambio climático en el patrón de lluvias en São Carlos-SP, Brasil. Estudios Geográficos, 73, 325-331. https://doi.org/10.3989/estgeogr.201212

Zandonadi, L. et al. (2016). Changes in Precipitation Extremes in Brazil (Paraná River Basin). Theoretical and Applied Climatology, 123, 741-756.

https://doi.org/10.1007/s00704-015-1391-4

Zilli, M. T. et al. (2017). A Comprehensive Analysis of Trends in Extreme Precipitation over Southeastern Coast of Brazil. International Journal of Climatology, 37, 2269-2279. https://doi.org/10.1002/joc.4840 